\title{
ANALISIS UNJUK KERJA RANCANGAN STEAM CONDENSATION TANK BERBASIS SIMULASI SOFTWARE
}

\author{
Dedy Haryanto, Ainur Rosidi, Giarno, G. Bambang Heru K., Susyadi, Mulya Juarsa \\ Pusat Teknologi dan Keselamatan Reaktor Nuklir, \\ Badan Tenaga Nuklir Nasional (BATAN) \\ Kawasan Puspiptek Serpong, Tangerang Selatan, 15314, Indonesia \\ *e-mail address: dedy.haryanto@batan.go.id
}

\begin{abstract}
ABSTRAK
ANALISIS UNJUK KERJA RANCANGAN STEAM CONDENSATION TANK BERBASIS SIMULASI SOFTWARE. Steam condensation tank merupakan salah satu komponen pada fasilitas Passive Helical Coil Condensation System (PaHCCS) pada PASCONEL yang berfungsi sebagai kondensor uap bertekanan. Steam condensation tank didesain menggunakan tube stainless steel 304 (SS 304) dengan diameter luar $600 \mathrm{~mm}$ dan ketebalan $9,53 \mathrm{~mm}$ serta ketinggian total 2970,8 mm. Steam condensation tank dioperasikan pada tekanan 20 bar, temperatur diatas $100^{\circ} \mathrm{C}$ dan dilengkapi dengan helical coil tube sebagai pengambil kalor pada uap bertekanan. Simulasi unjuk kerja rancangan steam condensation tank ini bertujuan untuk mengetahui keselamatan dan keamanan saat dioperasikan. Analisis unjuk kerja dilakukan menggunakan software CATIA, dimana pemodelan 3-dimensi rancangan steam condensation tank dioperasikan secara simulasi dengan 1,5 kali dari tekanan dan temperatur operasional. Hasil analisis kekuatan mekanik mendapatkan tegangan mekanik terbesar sebesar $9,57 \times 10^{7} \mathrm{~N} / \mathrm{m}^{2}$ pada bagian tengah shell rancangan steam condensor tank. Tegangan mekanik tersebut tidak berdampak pada rancangan steam condensor tank berbahan SS 304 karena besar tegangan mekanik yang terjadi lebih kecil daripada yield strength material SS 304 yaitu sebesar $1,73 \times 10^{8} \mathrm{~N} / \mathrm{m}^{2}$ dan masih berada didaerah elastisnya . Translational displacement maksimal yang terjadi pada rancangan steam condensor tank sebesar 6,2 mm adalah sangat kecil dan 1/500 dari ukuran total panjang rancangan steam condensor tank. Dengan demikian rancangan steam condensor tank aman untuk digunakan sebagai sarana penelitian.
\end{abstract}

Kata kunci: Steam Condensation Tank, PASCONEL, tegangan mekanik, translational displacement

\section{ABSTRACT}

PERFORMANCE ANALYSIS OF STEAM CONDENSATION TANK DESIGN BASED ON SOFTWARE SIMULATION. Steam condensation tank is one of the components in the Passive Helical Coil Condensation System (PaHCCS) facility at PASCONEL which functions as a condenser for pressurized steam. The steam condensation tank is designed using a 304 stainless steel tube (SS 304) with an outer diameter of $600 \mathrm{~mm}$ and a thickness of $9.53 \mathrm{~mm}$ and a total height of $2970.8 \mathrm{~mm}$. Operated at a pressure of 20 bar, temperatures above $100^{\circ} \mathrm{C}$ and equipped with a helical coil tube as heat sink for pressurized steam. The simulation of the steam condensation tank design performance aims to see safety and security when it is operated. Performance simulation is carried out using CATIA software, where the 3-dimensional modeling of the steam condensation tank design is simulated with 1.5 times the operating pressure and temperature. The results of the analysis of mechanical strength obtained the greatest mechanical stress of $9.57 \times 10^{7} \mathrm{~N} / \mathrm{m}^{2}$ in the middle of the shell of the steam condenser tank design. The mechanical stress did not affect the design of the steam condenser tank with SS 304 material because the amount of mechanical stress that occurred was smaller than the yield strength of SS 304 material which was $1.73 \times 10^{8} \mathrm{~N} / \mathrm{m}^{2}$ and still in the elastic area. The maximum translational displacement that occurs in the steam condenser tank design of $6.2 \mathrm{~mm}$ is very small and is 1/500 of the total length of the steam condenser tank design. Thus, the steam condenser tank design is safe to use as a research facility.

Keywords: Steam condensation tank, PASCONEL, mechanical stress, translational displacement 


\section{PENDAHULUAN}

Reaktor modular daya kecil (Small Modular Reactor/SMR) merupakan jenis reaktor pembangkit listrik tenaga nuklir yang sangat prospektif untuk dibangun di Indonesia karena sangat unggul dari aspek keselamatan, flexibilitas pembangunan dan permodalan [1]. Desain dan kapasitas reaktor jenis ini cocok untuk dibangun didaerah terpencil dan didaerah yang padat penduduknya, selain itu biayanya lebih terjangkau dan waktu konstruksinya juga lebih cepat. Salah satu keunggulan desain SMR adalah menerapkan konsep sirkulasi alam/sistem pasif untuk memindahkan panas dari bahan bakar ke pembangkit uap baik untuk operasi normal maupun saat kecelakaan. Jenis dari SMR salah satunya adalah reaktor $\mathrm{NuScale}$ yaitu reaktor jenis integral Pressurized Water Reactor (iPWR) yang dapat menghasilkan daya listrik sebesar 50 Mw. Desain NuScale mengandalkan pendinginan dengan sistem pasif (tanpa menggunakan pompa) saat beroperasi normal dan saat terjadi kecelakaan. Sistem pendinginan sistem pasif ini digunakan untuk pembuangan panas peluruhan (decay heat removal system) dan sistem pendinginan teras darurat (emergency core cooling system) [2].

Pembuatan fasilitas PAssive System Condensation Experiment Loop (PASCONEL) untuk simulasi mendukung salah satu tugas PTKRN untuk penilaian keselamatan PLTN besar dan SMR. Fasilitas PASCONEL adalah fasilitas uji simulasi untuk penelitian pendinginan pasif. Fasilitas ini mempunyai dua fasilitas uji simulasi yang dapat digunakan untuk dua topik penelitian yang berbeda. Fasilitas uji simulasi yang pertama adalah Passive Heat Pipe Steam Condensation System (PaHPSCS) yang digunakan untuk penelitian passive decay heat removal untuk PLTN besar menggunakan teknologi thermosypon. Fasilitas uji simulasi yang kedua adalah Passive Helical Coil Condensation System (PaHCCS) yang digunakan untuk penelitian proses pendinginan pasif untuk jenis PLTN SMR berbasis sirkulasi alam. Penelitian tersebut dilatar belakangi oleh kejadian kecelakaan pada PLTN Fukushima Daiichi, Maret 2011 di Jepang. Sehingga pemanfaatan sistem pasif sebagai sistem keselamatan bantu ketika terjadi kecelakaan menjadi salah satu pilihan. Sistem keselamatan pasif diharapkan dapat beroperasi ketika seluruh sistem reaktor mengalami kejadian station black out (SBO) [3]. Beberapa fasilitas uji simulasi telah dibuat oleh PTKRN untuk melakukan penelitian tentang pendinginan pasif, fasilitas-fasilitas tersebut adalah fasilitas uji FASSIP-01 kemudian dikembangkan dengan membangun fasilitas uji FASSIP-02 dan dilanjutkan dengan FASSIP-02 mod.1 serta FASSIP-03 NT yang menggunakan fluida Nanobubbles yang mulai dibuat 
desainnya pada tahun 2021. Serta telah dilakukan beberapa kajian, analisis serta perhitungan berdasarkan eksperimen menggunakan fasilitas tersebut [4-6].

Tahapan awal yang dilakukan pada pembuatan beberapa fasilitas uji adalah pembuatan desain fasilitas uji meliputi desain mekanik, desain instrumentasi dan desain kelistrikan. Pada bagian desain mekanik meliputi melakukan perhitungan baik secara perhitungan secara konvensional maupun perhitungan menggunakan code komputer sehingga didapat data untuk mendukung pembuatan gambar desain. Setelah gambar desain diperoleh dapat dilakukan analisis kekuatan mekanik dari masing-masing komponen pada fasilitas uji yang telah dilengkapi dengan jenis material yang digunakan. Analisis ini harus dilakukan sebelum tahapan pabrikasi dan pengoperasian, analisis kekuatan mekanik yang telah dilakukan pada desain komponen fasilitas PASCONEL lainnya yaitu pada desain pada komponen main steam generator [7].

Steam condensation tank merupakan salah satu komponen di fasilitas uji Passive Helical Coil Condensation System (PaHCCS) pada fasilitas PASCONEL, berfungsi sebagai pengambil kalor pada uap bertekanan 20 bar dan bertemperatur diatas $100^{\circ} \mathrm{C}$ yang dibangkitkan oleh main steam generator. Steam condensation tank termasuk mempunyai resiko kecelakaan yang tinggi dibandingkan dengan komponen lainnya pada fasilitas PASCONEL sehingga diperlukan simulasi unjuk kerja untuk mengetahui kekuatan mekanik pada rancangan steam condensation tank sebelum dilakukan pabrikasi dan selanjutnya digunakan sebagai kondensor uap bertekanan.

Penelitian bertujuan untuk mengetahui kekuatan mekanik meliputi tegangan mekanik dan translational displacement pada steam condensation tank terhadap beban tekanan dan temperatur, maka perlu dilakukan analisis kekuatan mekanik dilakukan menggunakan software CATIA. Tahapan analisis meliputi; pembuatan model 3 dimensi steam condensation tank sesuai dengan desain yang sudah diperoleh, pemberian restrain pada model 3 dimensi, pemberian beban berupa tekanan dan temperatur, pengujian kekuatan mekanik sehingga akan diketahui tegangan mekanik dan translational displacement pada model 3 dimensi [8]. Dengan membandingkan besar tegangan mekanik yang terjadi pada model 3 dimensi steam condensation tank dengan yield strength material yang digunakan yaitu SS 304 maka dapat diketahui kekuatan mekaniknya [9]. Besar translational displacement yang terjadi diharapkan tidak terlalu besar sehingga tidak mengakibatkan perubahan bentuk pada Steam Condensation Tank. 


\section{FASILITAS PASCONEL}

Diagram alir fasilitas uji PASCONEL seperti digambarkan pada Gambar 1. Aliran pada fasilitas uji simulasi Passive Heat Pipe

\section{Stream Condensation System (PaHPSCS)}

dimulai dari main steam generator yang berfungsi membangkitkan uap air bertekanan 10 bar pada temperatur diatas $100{ }^{\circ} \mathrm{C}$.

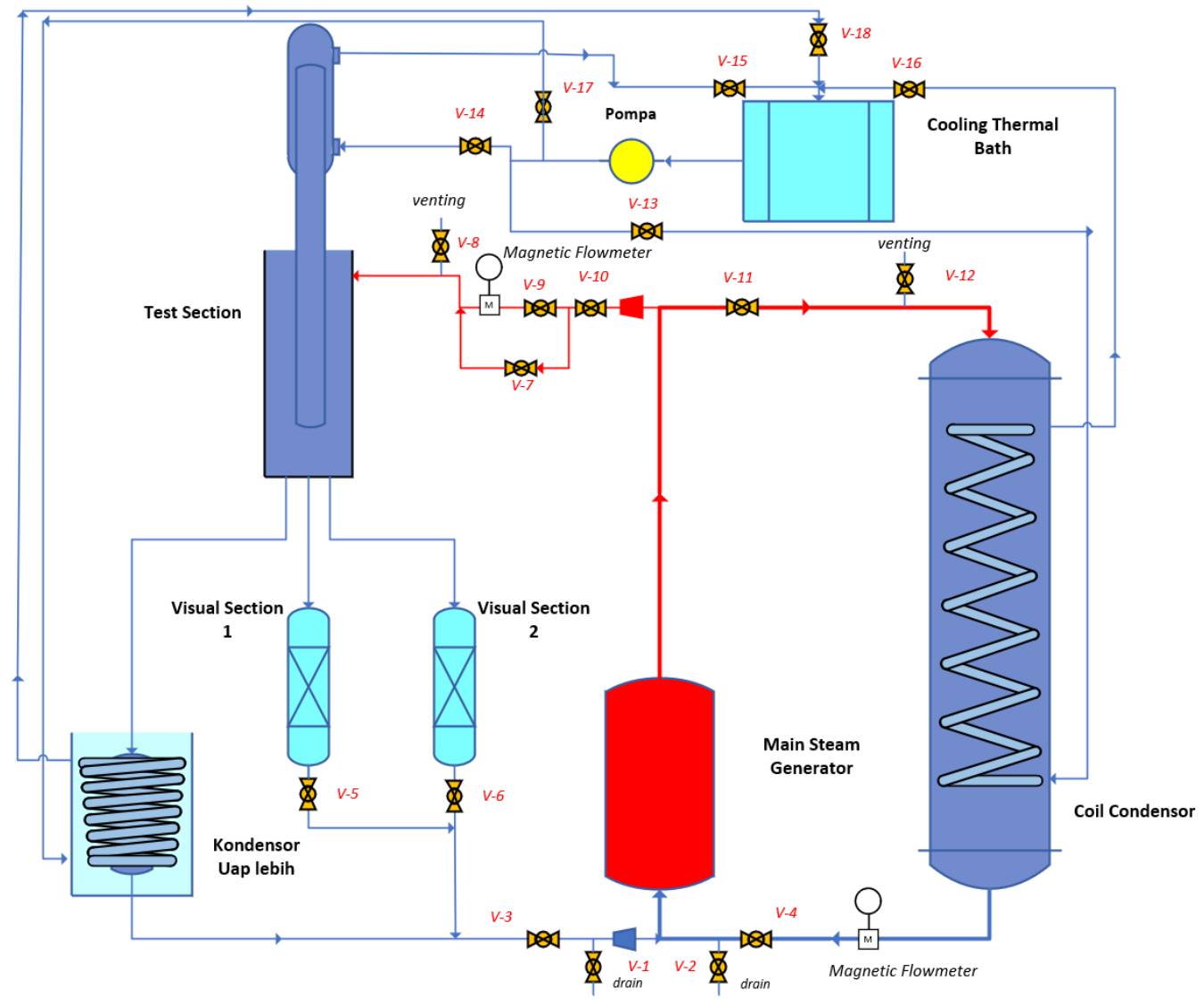

Gambar 1. Diagram alir fasilitas uji PASCONEL

Uap bertekanan tersebut mengalir menuju test section yang terdiri dari tabung pengumpul uap bertekanan dan heat pipe. Sehingga uap bertekanan tersebut akan didinginkan oleh heat pipe dan temperatur lingkungan. Karena adanya pendinginan tersebut maka uap air akan mengalami penurunan temperatur dan perubahan wujud menjadi air kembali serta dialirkan melalui tiga saluran yang berbeda. Saluran pertama untuk uap yang telah berubah menjadi air karena didinginkan oleh temperatur lingkungan dan mengalami pengembunan pada dinding bagian dalam tabung pengumpul uap dialirkan ke visual section 1 yang menggunakan material gelas pyrex. Uap yang telah berwujud menjadi air karena pendinginan oleh heat pipe, dialirkan ke visual section 2 yang menggunakan material gelas pyrex juga. Sedangkan uap yang telah mengalami penurunan temperatur tetapi masih berwujud uap dialirkan ke precooler 
untuk selanjutnya didinginkan lagi sehingga berubah wujud menjadi air. Air dari visual section 1, visual section 2 dan precooler dialirkan kembali menuju main steam generator untuk diubah menjadi uap bertekanan kembali. Pada heat pipe dilengkapi dengan water jacket pada bagian pendinginnya yang air pendinginnya disuplai oleh cooling thermal bath dan disirkulasikan menggunakan pompa. Pada precooler dilengkapi dengan helical tube yang berfungsi untuk mengkondensasi uap sisa dari tabung pengumpul uap. Pada helical tube air pendinginnya disuplai juga oleh cooling thermal bath dengan menggunakan pompa.

Aliran pada fasilitas uji simulasi Passive Coil Steam Condensation System (PaCSCS) dimulai juga dari main steam generator yang berfungsi membangkitan uap air bertekanan 10 bar sampai dengan 20 bar pada temperatur diatas $100 \quad{ }^{\circ} \mathrm{C}$. Uap bertekanan yang sudah terbentuk dialirkan ke steam condensation tank. Uap bertekanan akan didinginkan oleh air dari sistem sekunder yang dialirkan didalam helical tube steam condensation tank. Sistem sekunder ini terdiri dari cooling thermal bath yang telah dilengkapi dengan refrigerator untuk menurunkan temperatur air. Air dingin dari cooling thermal bath dialirkan oleh pompa menuju ke helical tube pada steam condensation tank untuk mengubah uap bertekanan menjadi air. Air selanjutnya dialirkan ke main steam generator untuk diubah menjadi uap bertekanan kembali. Sirkulasi yang terjadi pada fasilitas uji PaCSCS adalah sirkulasi alamiah juga seperti yang terjadi pada fasilitas uji PaHPSCS.

\section{Desain Steam condensor tank}

Komponen steam condensation tank merupakan komponen inti dari fasilitas uji Passive Coil Steam Condensation System (PaCSCS). Komponen ini merupakan komponen terbesar pada loop PASCONEL dengan ketinggian total $2970,8 \mathrm{~mm}$, diameter nominal $600 \mathrm{~mm}$ pada bagian Shell menggunakan material stainless stell 304. Steam condensation tank merupakan salah satu komponen pada fasilitas PASCONEL yang berfungsi untuk mengkondensasi uap bertekanan 10-20 bar sehingga berubah menjadi air. Bentuk dan dimensi steam condensation tank adalah seperti diperlihatkan pada Gambar 2. 


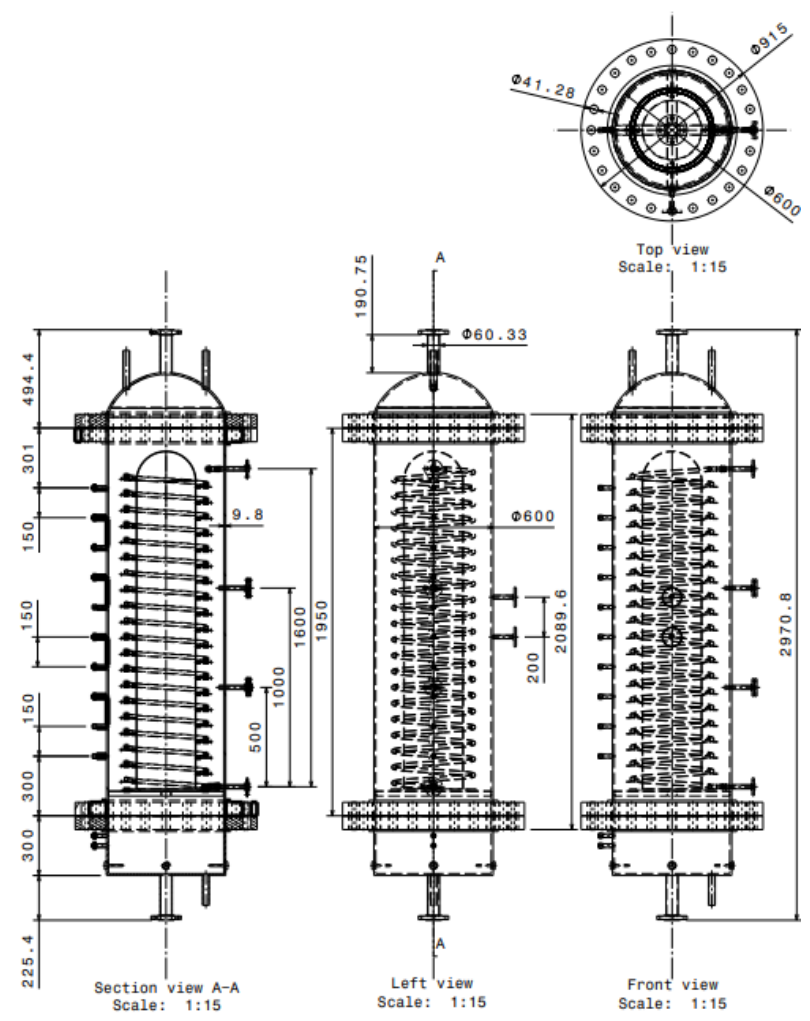

Gambar 2. Desain Steam Condensation Tank

Desain Steam Condensation Tank menggunakan material pipa stainless stell 304. Bagian Shell berdiameter $600 \mathrm{~mm}$ dengan ketebalan 9,8 mm, saluran input dan output menggunakan pipa stainless stell 304 Schedulle 20 (sch. 20) berdiameter 50,8 mm. Flange menggunakan flange tipe slip on dengan spesifikasi slip on 150 lb flange 50,8 mm [8]. Penampung air kondensat dilengkapi juga dengan 4 buah pemanas listrik dengan daya masing-masing $5 \mathrm{~kW}$. Sehingga daya total pemanas listrik mencapai $20 \mathrm{~kW}$ dan pengoperasian pemanas listrik dikontrol secara otomatis menggunakan pemrograman LabView. Pada bagian helical tube menggunakan tube stainless stell 304 sch. 20 berdiameter $12,7 \mathrm{~mm}$. Panjang total helical tube $25 \mathrm{~m}$ dan berbentuk helical dengan diameter center helical $400 \mathrm{~mm}$, tinggi helical
$1600 \mathrm{~mm}$, jarak antar tube (pitch) 80,2 mm dan jumlah lingkaran helical 20 buah. Helical tube ini dilengkapi dengan anulus yang sekaligus berfungsi sebagai support helical. Untuk menghubungkan bagian Shell dan bagian helical menggunakan type joint Swagelok. Penggunaan jenis ini dikarenakan sempitnya ruangan antara shell dan helical tube disamping itu helical tube didesain dapat dengan mudah untuk dibongkar pasang untuk diganti dengan ukuran yang bervariasi. steam condensation tank dilengkapi juga dengan level meter yang dioperasikan secara elektronik. Hal ini untuk sistem keamanan pengoperasian pemanas listrik karena jika tidak ada air dapat mengakibatkan pemanas listrik mengalami kerusakan jika tetap dioperasikan. Steam condensation tank dilengkapi dengan alat ukur temperatur 
analog, alat ukur pressure gauge, safety valve dan safety release valve. Bagian dan

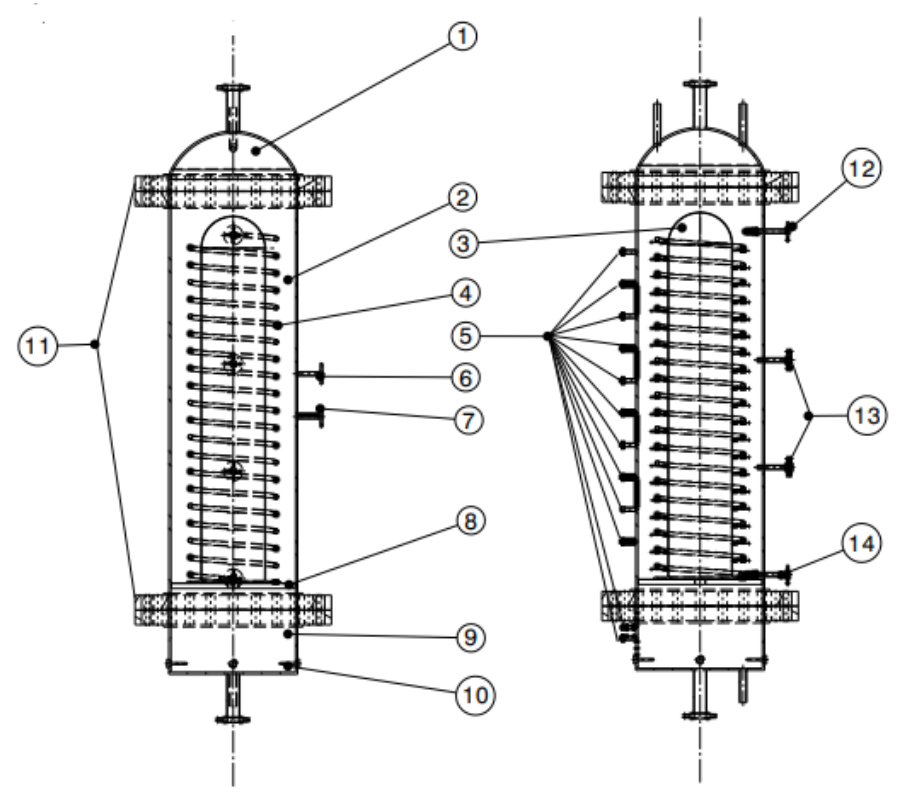

komponen detail steam condensation tank dapat dilihat pada Gambar 3

Gambar 3. Bagian-bagian Steam Condensation Tank

\section{METODOLOGI}

Tahapan pengujian secara simulasi untuk menganalisis kekuatan mekanik adalah sebagai berikut ;

1. Pembuatan model 3-dimensi.

Pada tahapan ini dilakukan pembuatan model 3-dimensi steam condensation tank dengan mengacu pada rancangan. Model tersebut dilengkapi dengan sifat-sifat material yang digunakan pada rancangan sebagai data masukan.

2. Pembebanan.

Pembebanan maksimal yang diberikan pada steam condensation tank adalah berupa tekanan dan temperatur. Pembebanan diberikan dengan tekanan sebesar 1,5 kali dari tekanan dan temperatur operasional yaitu sebesar 30 bar dan $319,5^{\circ} \mathrm{C}(592,5 \mathrm{~K})$.
Keterangan :

1. Cap Coil Condensor

2. Body Coil Condensor

3. Anulus

4. Helical tube

5. Housing termokopel

6. Pressure gauge

7. Temperatur gauge

8. Support anulus

9. Penampung air kondensat

10. Pemanas listrik

11. Flanges

12. Output helical tube

13. Spare output helical tube

14. Input helical tube

\section{Restrain.}

Restrain mensimulasikan model 3-dimensi steam condensation tank pada kondisi statis. Restrain harus diberikan pada model agar simulasi dapat dilakukan.

4. Pengujian tegangan mekanik dan traslational displacement.

Model 3-dimensi diberikan input berupa sifat-sifat material, beban dan restrain. Selanjutnya dilakukan simulasi untuk mengetahui besaran tegangan mekanik dan translasional displacement yang terjadi. Besaran tegangan mekanik dibandingkan dengan yield strength material yang digunakan sehingga dapat diketahui kekuatan mekanik desain steam condensation tank. Sifat-sifat mekanik dari material stainless steel 304 ditunjukkan pada tabel 1. 
Tabel 1. Sifat mekanik bahan dan stainless steel 304 [9]

\begin{tabular}{ll}
\hline Parameter & Nilai \\
\hline Young Modulus & $1,93 \times 10^{11} \mathrm{~N} / \mathrm{m}^{2}$ \\
Poisson Ratio & 0,29 \\
Density & $7800 \mathrm{~kg} / \mathrm{m}^{3}$ \\
Thermal Expantion & $1,72 \times 10^{-5} \mathrm{~K}^{-1}$ \\
Yield Strength & $1,7 \times 10^{8} \mathrm{~N} / \mathrm{m}^{2}$ \\
\hline
\end{tabular}

\section{HASIL DAN PEMBAHASAN}

Mengacu pada ASME B31.3 diperoleh shell steam condensation tank menggunakan material Welded pipe Stainless Steel 304 berdiameter $600 \mathrm{~mm}$ sch. 20. Pengujian dilakukan secara simulasi menggunakan software CATIA yang dilakukan secara simulasi. Dalam pengujian secara simulasi untuk mengetahui kekuatan mekanik suatu rancangan diperlukan data masukan berupa sifat mekanik dari material yang digunakan. Pengujian secara simulasi dilakukan pada rancangan steam condensor tank mengikuti peraturan Menteri Ketenagakerjaan Republik Indonesia dimana rancangan steam condensor tank termasuk dalam bejana tekan. Sehingga pengujian dilakukan mengikuti peraturan yaitu besar tekanan dan temperatur pengujian sebesar 1,5 kali dari tekanan dan temperatur operasional [10]. Pengujian secara simulasi dilakukan dengan restrain dan pembebanan seperti yang ditunjukkan pada Gambar 4.
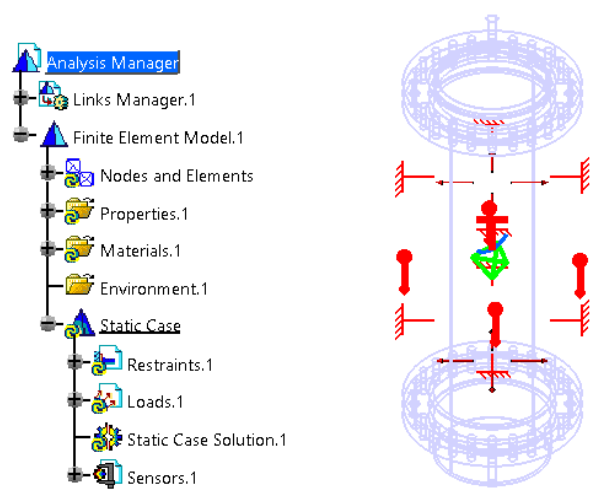

Gambar 4. Restrain dan pembebanan pada model 3 dimensi rancangan steam condensor tank

Pada pemodelan 3 dimensi menggunakan restrain bertipe clamp yang mensimulasikan bahwa rancangan steam condensor tank pada posisi disupport tetapi support tersebut masih memungkinkan adanya bergeseran kearah atas $(\mathrm{Z}+)$ dan kearah bawah (Z-). Pembebanan berupa tekanan sebesar 30 bar menekan merata pada bagian dinding dalam model. Temperatur sebesar $150{ }^{\circ} \mathrm{C}(423 \mathrm{~K})$ mengenai dinding bagian dalam rancangan steam condensor tank dan adanya percepatan gravitasi sebesar $10 \mathrm{~m} / \mathrm{s}^{2}$ yang mengenai seluruh bagian model 3 dimensi. Hasil perhitungan secara simulasi yang diperoleh ditunjukkan pada Gambar 5. 


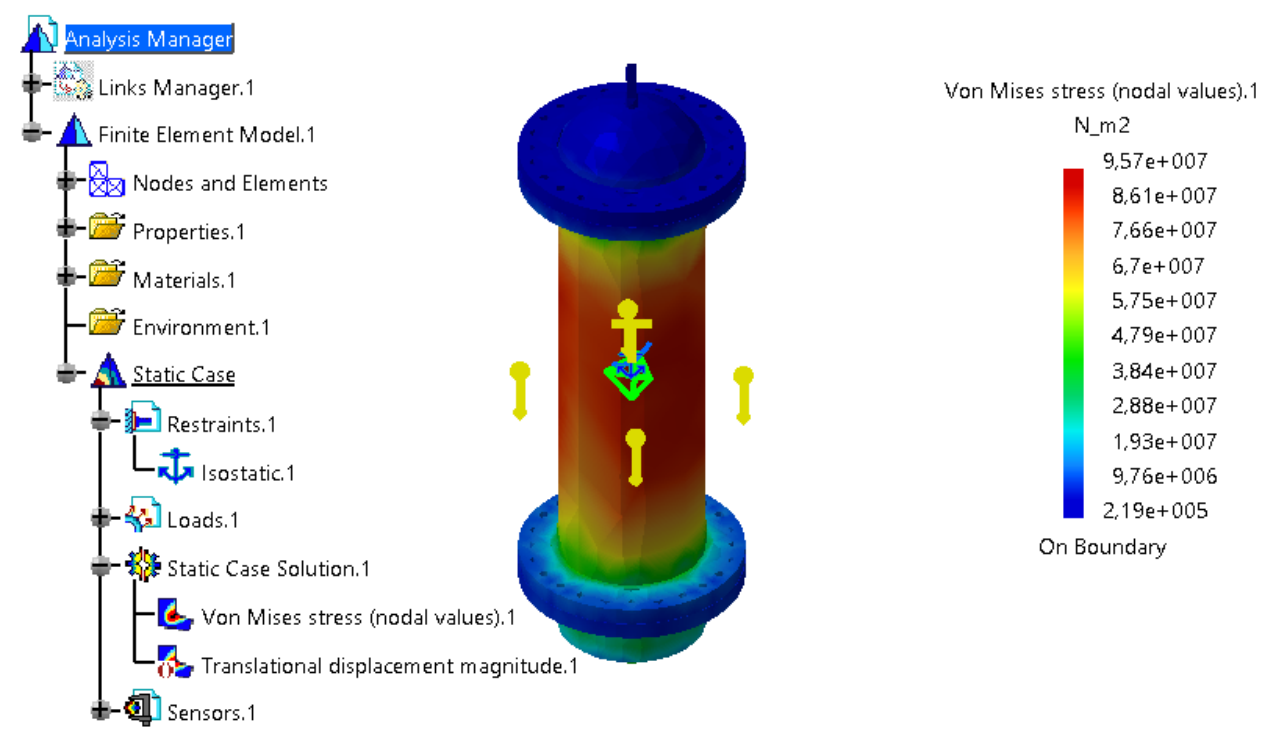

Gambar 5. Tegangan mekanik yang terjadi pada rancangan steam condensor tank

Pengujian tegangan mekanik ini bertujuan untuk mengetahui terjadinya stress akibat adanya beban berupa tekanan dan temperatur yang mengenai rancangan steam condensor tank. Hasil pengujian secara simulasi untuk mengetahui besar tegangan mekanik yang terjadi pada rancangan steam condensor tank ditunjukkan pada Gambar 5. Hasil pengujian menujukkan adanya tegangan mekanik terbesar sebesar 9,57 $\mathrm{x}$ $10^{7} \mathrm{~N} / \mathrm{m}^{2}$ pada bagian tengah shell rancangan steam condensor tank (berwarna merah). Tegangan mekanik tersebut tidak berdampak pada rancangan steam condensor tank yang bermaterial SS 304 karena besar tegangan mekanik yang terjadi lebih kecil daripada yield strength material SS 304 yaitu sebesar $1,73 \times 10^{8} \mathrm{~N} / \mathrm{m}^{2}$ [9] sehingga masih berada didaerah plastis dari material SS 304. Dimana apabila beban berupa tekanan dan temperatur dihilangkan maka stress akan hilang.
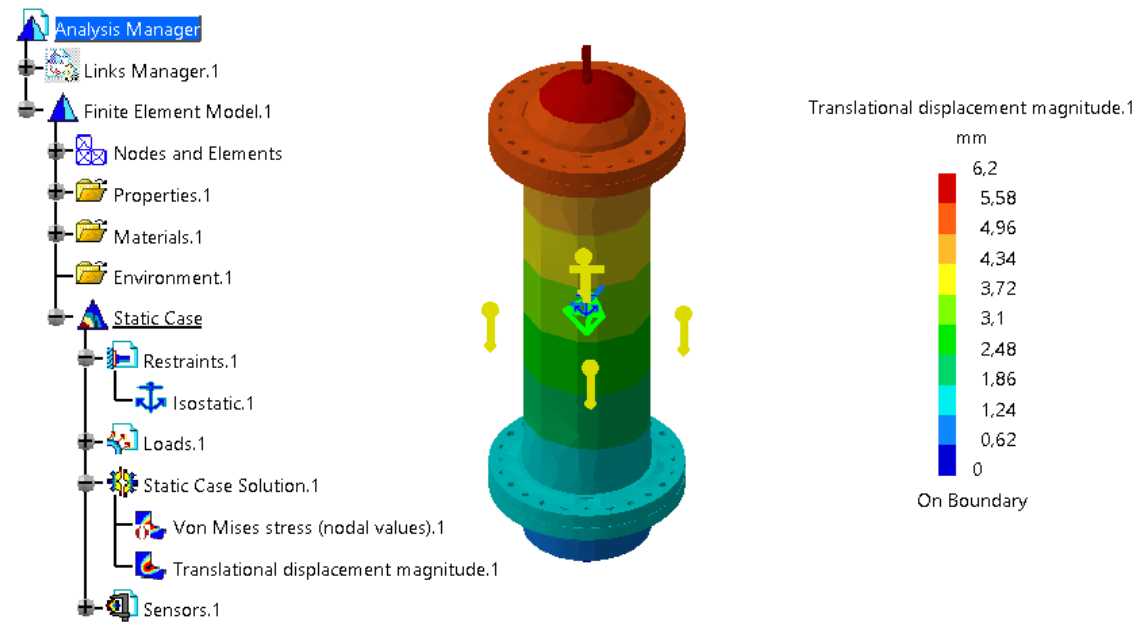

Gambar 6. Translational displacement yang terjadi pada rancangan steam condensor tank 
Hasil pengujian secara simulasi untuk mengetahui besar translational displacement yang terjadi pada rancangan steam condensor tank ditunjukkan pada Gambar 6. Pengujian ini bertujuan untuk mengetahui terjadinya perubahan bentuk pada rancangan steam condensor tank saat dikenai beban berupa tekanan dan temperatur. Hasil pengujian secara simulasi menunjukkan besar translational displacement maksimal yang terjadi pada rancangan steam condensor tank sebesar 6,2 mm. Jika dibandingkan dengan panjang total rancangan steam condensor tank, translational displacement yang terjadi hanya 1/500 dari ukuran total panjang rancangan steam condensor tank. Hasil perbandingan tersebut menunjukkan bahwa translational displacement yang terjadi sangat kecil sehingga tidak merubah bentuk rancangan steam condensor tank. Translational displacement sebesar $6,2 \mathrm{~mm}$ kearah atas tersebut sangat mempengaruhi pemipaan pada bagian output rancangan steam condensor tank karena ada pertambahan panjang totalnya. Untuk mengatasi hal itu pada pemipaan output steam condensor tank yang mendatar dilengkapi dengan flexible hose yang berfungsi untuk mereduksi translational displacement sebesar $6,2 \mathrm{~mm}$.

\section{KESIMPULAN}

Untuk mengetahui keandalan dan keselamatan rancangan steam condensor tank dapat dilakukan pengujian secara simulasi menggunakan software CATIA. Hasil analisis secara simulasi mendapatkan tegangan mekanik terbesar sebesar $9,57 \times 10^{7} \mathrm{~N} / \mathrm{m}^{2}$ pada bagian tengah shell rancangan steam condensor tank. Tegangan mekanik tersebut tidak berdampak pada rancangan steam condensor tank yang bermaterial SS 304 karena besar tegangan mekanik yang terjadi lebih kecil daripada yield strength material SS 304 yaitu sebesar 1,73 x $10^{8} \quad \mathrm{~N} / \mathrm{m}^{2}$. Translational displacement maksimal yang terjadi pada rancangan steam condensor tank sebesar 6,2 mm adalah sangat kecil dan 1/500 dari ukuran total panjang rancangan. Translational displacement sebesar $6,2 \mathrm{~mm}$ kearah atas tersebut sangat mempengaruhi pemipaan pada bagian output rancangan steam condensor tank karena ada pertambahan panjang totalnya. Untuk mengatasi hal itu pada pemipaan output steam condensor tank yang mendatar dilengkapi dengan flexible hose yang berfungsi untuk mereduksi translational displacement sebesar $6,2 \mathrm{~mm}$.

\section{UCAPAN TERIMAKASIH}

Kami ucapkan terima kasih atas dukungan yang diberikan oleh; DIPA PTKRN-BATAN yang telah membiayai penelitian, Kepala Pusat Teknologi dan 
Keselamatan Reaktor Nuklir, Koordinator

BPFKR selaku atasan langsung dan temanteman Peneliti dan Pranata Nuklir di Subbidang Fasilitas Termohidrolika atas diskusi teknis.

\section{DAFTAR PUSTAKA}

[1] HIDAYATULLAH, H., S. SUSYADI, and M.H. SUBKI, Design and technology development for small modular reactorsSafety expectations, prospects and impediments of their deployment. Progress in Nuclear Energy, 2015. 79: p. 127-135.

[2] IAEA, Advances in small modular reactor technology developments: A Supplement to:IAEA Advanced Reactors Information System (ARIS), 2018, International Atomic Energy Agency Vienna, Austria.

[3] D. C. SUN, Y. LI, Z. XI, Y. F. ZAN, P. Z. LI, and W. B. ZHUO, "Experimental evaluation of safety perfomance of emergency passive residual heat removal system in HPR1000”, Nuclear Engineering and Design, vol. 318, pp. 54-60, 2017/07/01/ 2017.

[4] ANHAR $\mathrm{R}$ ANTARIKSAWAN, $\mathrm{dkk}$,"Premilininary investigation of natural circulation stability in FASSIP-01 experimental facility using RELAP5 code", Jurnal AIP Conference Proceedings, Jilid 2001, Terbitan 1, 16 Agustus, (2018)070003.

[5] ANHAR $\mathrm{R}$ ANTARIKSAWAN, dkk,"Simulation of operational conditions of FASSI-02 natural circulation cooling system experimental loop", Jurnal Sains dan
Teknologi Nuklir Indonesia, Vol 19, No 1, (2018).

[6] MULYA JUARSA, dkk,"Preliminary Investigation on Natural Circulation Flow using CFD and Calculation Base on Experimental Data Pre-FASSIP-02", Jurnal IOP Conference Series: Journal of Physics, Jilid 1198, Terbitan 2, April, (2019)022073.

[7] DEDY HARYANTO, GIARNO, G. BAMBANG HERU K, MULYA JUARSA, "Analisis Kekuatan Mekanik Main Steam Generator pada Fasilitas PASCONEL", Prosiding Seminar Nasional Teknologi Energi Nuklir 2020 (ISSN:2355-7524), 18 November 2020.

[8] Mhd. DAUD PINEM,S.T., CATIA Si Jago Desain Tiga Dimensi, Kawah Media, Jl. H. Montong No. 57, Ciganjur-Jagakarsa, Jakarta Selatan 12630, 2009.

[9] SAINI, M., et al., Mechanical Properties of Bimetallic Weld Joint between SA 516 Grade 65 Carbon Steel and SS 304 L For Steam Generator Application. life, 2014. 4: p.

[10] MENTERI KETENAGAKERJAAN REPUBLIK INDONESIA, Keselamatan dan Kesehatan Kerja Bejana Tekan dan Tangki Timbun, Peraturan Menteri Ketenagakerjaan Republik Indonesia Nomor 37 Tahun 2016. 